\title{
A Trial to Assess the Amount of Insulin Antibodies in Diabetic Patients by Surface Plasmon Resonance
}

\author{
Masahiko Kure, Yoshiya Katsura, Hiroshi Kosano*, Masayuki NoritaKe, \\ Toshiya Watanabe, Yoshiki IwaKI, Hideo NishigORI* and Takeshi MATSUOKA
}

\begin{abstract}
Objective To measure the amount and affinity of insulin antibodies, we performed a trial to establish a new method for quantitative and qualitative analysis of these antibodies by using surface plasmon resonance (BIAcore $^{\mathrm{TM}}$ system).

Methods Real-time detection of insulin antibody interaction and kinetic analysis were performed using the BIAcore $^{\mathrm{TM}}$ system.

Patients or Materials Eight diabetic patients with insulin antibodies and whose fasting total immunoreactive insulin levels were more than $100 \mu \mathrm{U} / \mathrm{ml}$ were selected. The patients with and without recurrent hypoglycemia were classified into hypoglycemic episode-positive or hypoglycemic episode-negative groups, respectively. Seven diabetic patients without insulin antibodies were selected as controls.

Results In the 8 patients, the concentration of insulin antibodies ranged from 2.91 to $16.3 \mu \mathrm{g} / \mathrm{ml}$ and insulin antibodies were not detected in the control group. The apparent KD (dissociation constant) and kd (the dissociation rate constant) values of the patients were much larger than those seen for the anti-human insulin monoclonal antibody. The KD values were significantly higher in the hypoglycemic episode-positive group than in the hypoglycemic episode-negative group $(p<0.05)$. No significant differences in the concentration, the ka (the association rate constant) and the $k d$ values were noted between the groups.

Conclusion The data suggests that insulin antibodies of the patients have an apparently lower affinity status in sera as compared with that for the anti-human insulin monoclonal antibody, and dissociate easily from the immune-complex in the sera, especially in cases where there is recurrent hypoglycemia in the patients. Therefore in-
\end{abstract}

sulin antibody characteristics are one of the causative factors in hypoglycemic episodes.

(Internal Medicine 44: 100-106, 2005)

Key words: diabetes mellitus, insulin antibody, surface plasmon resonance, Scatchard analysis, hypoglycemia

\section{Introduction}

In diabetic patients treated with exogenous insulin, insulin antibodies are sometimes detected in the sera (1). Although the wide use of recombinant human insulin has reduced the production of insulin antibodies $(2,3)$, Fineberg et al (4) reported that insulin antibodies still appear in $40-60 \%$ of diabetic patients treated with human insulin resulting in problems such as insulin resistance or hypoglycemia.

High-affinity insulin antibodies frequently induce insulin resistance in patients $(5,6)$ and low-affinity antibodies induce hypoglycemia due to the dissociation of high amounts of insulin from the insulin antibody complex $(4,7)$. However the actual status and effects that can be attributed to the antibody affinities are still unknown.

Up until the present, the affinity of insulin antibodies has typically been measured by a traditional binding assay and analyzed by a Scatchard analysis (8). This method is widely used for affinity measurements in many facilities, but it is basically a method used to measure high-affinity, i.e., a one component (monoclonal) antigen-antibody reaction. If antibodies are found to be polyclonal, we usually hypothesize that there is the existence of more than two components, such as high-affinity and low-affinity antibodies, and fit the dissociation constant (KD) through calculations. However, the Scatchard analysis sometimes does not adequately mea-

From the Fifth Department of Internal Medicine, Tokyo Medical University (Kasumigaura Hospital), Ibaraki and *Faculty of Pharmaceutical Sciences, Teikyo University, Kanagawa

Received for publication February 17, 2004; Accepted for publication August 28, 2004

Reprint requests should be addressed to Dr. Masahiko Kure, the Fifth Department of Internal Medicine, Tokyo Medical University, 3-20-1 Chuou Ami, Inashiki, Ibaraki 300-0395 
sure the low-affinity antibodies (KD less than about $10^{-4} \mathrm{M}$ ) because the low-affinity interaction is usually reversible and easily dissociates the ligand from the complex.

Since the introduction of the BIAcore ${ }^{\mathrm{TM}}$ system in 1991 $(9,10)$, the use of surface plasmon resonance technology has facilitated kinetic analysis of molecular interactions. This method is especially suitable for determining low-affinity antigen-antibody interactions such as lectin and sugar, and reversible protein interactions such as cellular signal transduction.

In the present study, we have developed a new method using the BIAcore ${ }^{\mathrm{TM}}$ system to assess the apparent affinity of insulin antibodies in patients with diabetes mellitus. It enables us to measure both the amount and the apparent affinity of insulin antibodies and may reveal the clinical significance of insulin antibodies.

\section{Materials and Methods}

\section{Study subjects and sample collection}

All patients gave prior informed consent. Eight diabetic patients with insulin antibodies in their sera and whose fasting total immunoreactive insulin (TIRI) levels, as measured by the polyethylene glycol (PEG) method, were more than $100 \mu \mathrm{U} / \mathrm{ml}$ were selected for the present study. Patients that exhibited recurrent hypoglycemia and unstable blood glucose levels, including unexpected hyperglycemia, were classified as hypoglycemic episode-positive patients (patients No. 1-No. 4). The other 4 patients (patients No. 5-No. 8) that had no recurrent hypoglycemia were classified as hypoglycemic episode-negative patients. Seven diabetic patients without insulin antibodies were selected as the corresponding control group. Serum samples were immediately frozen and TIRI, free immunoreactive insulin (FIRI) and ${ }^{125}$ I-labeled human insulin binding (normal range, $<5 \%$ ) were measured according to the method reported by Uchigata et al (11). FIRI was measured after the precipitation of antibody-bound insulin with PEG.

Table 1 shows the demographics and medical characteristics for the patients with the insulin antibody and the controls that lacked the insulin antibody. Although the sex ratios varied somewhat, the age ranges and body mass index (BMI) for the patients were not grossly different. All subjects in the control group were treated with human insulin alone. In 8 patients with insulin antibodies, 4 had been treated with human insulin alone and 4 had been treated with both animal and human insulin in the past. The duration of the insulin therapy was longer in patients with the insulin antibody than in the control group but there was no difference between the groups with regard to current insulin dosage. There was no significant difference observed between the hypoglycemic episodepositive and -negative groups for age, sex, BMI, insulin species, duration of insulin treatment and current insulin dosage. The hemoglobin $\mathrm{A}_{\mathrm{lc}}\left(\mathrm{HbA}_{\mathrm{lc}}\right)$ levels shown in the table are for the data obtained at the time when insulin antibodies were measured.

\section{Insulin antibody interactions (BIAcore ${ }^{T M}$ analysis)}

Real-time detection of insulin antibody interaction and kinetic analysis were performed using the BIAcore ${ }^{\mathrm{TM}}$ system (BIAcore 2000, Biacore AB, Uppsala, Sweden). This instrument detects changes in the refractive index of the solution close to the surface of the sensor chip. To perform the analysis, one reactant (the ligand) is immobilized in a dextran ma-

Table 1. Summary of Clinical Characteristics of the Patients

\begin{tabular}{|c|c|c|c|c|c|c|c|c|c|c|c|c|c|c|}
\hline \multirow{2}{*}{$\begin{array}{l}\text { Patient } \\
\text { no. }\end{array}$} & \multirow{2}{*}{$\begin{array}{c}\text { Age } \\
\text { (years) }\end{array}$} & \multirow{2}{*}{$\begin{array}{c}\text { Sex } \\
(\mathrm{M} / \mathrm{F})\end{array}$} & \multirow{2}{*}{$\begin{array}{c}\text { BMI } \\
\left(\mathrm{kg} / \mathrm{m}^{2}\right)\end{array}$} & \multirow{2}{*}{$\begin{array}{l}\text { Insulin } \\
\text { species }\end{array}$} & \multirow{2}{*}{$\begin{array}{c}\text { Duration of } \\
\text { insulin treatment } \\
\text { (year) }\end{array}$} & \multirow{2}{*}{$\begin{array}{c}\text { Current } \\
\text { insulin dosage } \\
(/ \text { day })\end{array}$} & \multirow{2}{*}{$\begin{array}{c}\text { Hypoglycemic } \\
\text { episode }\end{array}$} & \multirow{2}{*}{$\begin{array}{l}\text { GADA } \\
(\mathrm{U} / \mathrm{ml})\end{array}$} & \multirow{2}{*}{$\begin{array}{c}\mathrm{HbA}_{\mathrm{lc}} \\
(\%)\end{array}$} & \multirow{2}{*}{$\begin{array}{c}\text { TIRI } \\
(\mu \mathrm{U} / \mathrm{ml})\end{array}$} & \multirow{2}{*}{$\begin{array}{c}\text { FIRI } \\
(\mu \mathrm{U} / \mathrm{ml})\end{array}$} & \multirow{2}{*}{$\begin{array}{l}{ }^{125} \text { I- insulin } \\
\text { binding } \\
(\%)\end{array}$} & \multicolumn{2}{|c|}{ HLA } \\
\hline & & & & & & & & & & & & & DR & DRB1 \\
\hline 1 & 60 & $\mathrm{~F}$ & 24.1 & human & 21 & R $28 \mathrm{U}, \mathrm{NPH} 10 \mathrm{U}$ & + & 9.5 & 7.4 & 153 & 5.0 & 49.6 & DR4 DR9 & 04050901 \\
\hline 2 & 69 & $\mathrm{~F}$ & 20.1 & bovine and human & 20 & Mix $30 \mathrm{U}$ & + & 0.4 & 10.1 & 678 & 25 & 65.4 & DR8 DR9 & 08030901 \\
\hline 3 & 85 & $\mathrm{~F}$ & 19.4 & bovine and human & 15 & Mix $14 U$ & + & 0.4 & 14.7 & 1000 & 5.0 & 70.0 & DR4 DR9 & - \\
\hline 4 & 60 & $\mathrm{~F}$ & 23.6 & human & 2 & Mix $16 U$ & + & 0.4 & 7.8 & 1250 & 8.2 & 76.9 & DR4 DR6 & 04051401 \\
\hline 5 & 74 & $\mathrm{~F}$ & 25.2 & human & 25 & R 66U & - & 0.4 & 9.4 & 2500 & 230 & 70.8 & DR2 DR6 & - \\
\hline 6 & 74 & $\mathrm{~F}$ & 23.8 & human & 2 & NPH $14 \mathrm{U}$ & - & 0.4 & 6.8 & 100 & 5.0 & 76.5 & DR4 & 04010405 \\
\hline 7 & 64 & $\mathrm{~F}$ & 20.5 & bovine and human & 16 & NPH $24 \mathrm{U}$ & - & 0.4 & 6.8 & 449 & 7.0 & 75.3 & N.D. & N.D. \\
\hline 8 & 78 & $\mathrm{~F}$ & 24.1 & bovine and human & 17 & Mix 28U & - & 0.4 & 12.1 & 4100 & 7.0 & 85.4 & DR9 & 09010901 \\
\hline
\end{tabular}

\begin{tabular}{|c|c|c|c|c|c|c|c|c|c|c|c|c|c|c|}
\hline \multicolumn{15}{|c|}{ Control } \\
\hline 9 & 42 & $\mathrm{~F}$ & 29.0 & human & 1 & $\operatorname{Mix} 28 U$ & - & 0.4 & 9.9 & 30.4 & 30.2 & 2.0 & N.D. & N.D. \\
\hline 10 & 49 & M & 19.3 & human & 1 & $\operatorname{Mix} 12 \mathrm{U}$ & - & 0.4 & 11.0 & 3.2 & 3.0 & 2.0 & N.D. & N.D. \\
\hline 11 & 70 & $\mathrm{~F}$ & 28.8 & human & 1 & Mix $20 U$ & - & 0.4 & 7.2 & 5.6 & 5.4 & 2.0 & N.D. & N.D. \\
\hline 12 & 62 & $\mathrm{~F}$ & 27.0 & human & 1 & $\operatorname{Mix} 24 U$ & - & 0.4 & 9.0 & 5.6 & 5.2 & 2.0 & N.D. & N.D. \\
\hline 13 & 69 & M & 27.7 & human & 25 & NPH $30 \mathrm{U}$ & - & 0.4 & 8.0 & 14.8 & 14.6 & 2.0 & N.D. & N.D. \\
\hline 14 & 87 & $\mathrm{~F}$ & 21.8 & human & 1 & R $24 \mathrm{U}, \mathrm{NPH} 6 \mathrm{U}$ & - & 0.4 & 12.0 & 5.6 & 5.4 & 2.0 & N.D. & N.D. \\
\hline 15 & 75 & $\mathrm{~F}$ & 20.9 & human & 1 & R $12 \mathrm{U}, \mathrm{NPH} 4 \mathrm{U}$ & - & 0.4 & 7.9 & 3.0 & 3.0 & 2.0 & N.D. & N.D. \\
\hline
\end{tabular}

BMI: body mass index, Insulin species: insulin species used in the past treatment, Hypoglycemic episode: hypoglycemic episode-positive patients exhibited recurrent hypoglycemia and unstable blood glucose levels including unexpected hyperglycemia, GADA: anti-glutamic acid decarboxylase antibody, TIRI: total immunoreactive insulin, FIRI: free immunoreactive insulin, ${ }^{125} \mathrm{I}$ - insulin binding: ${ }^{125} \mathrm{I}$-labeled human insulin binding, R: human regular insulin, NPH: human neutral protamine Hagedorn insulin, Mix: $30 \%$ regular and $70 \% \mathrm{NPH}$ insulin, N.D.: not determined. 
trix on the sensor chip. The sample containing the other reactant (the analyte) is injected over the CM5 sensor chip (Biacore $\mathrm{AB}$ ) surface using a controlled flow. Any change in surface concentration resulting from the interaction is detected as a surface plasmon resonance signal, and is expressed in resonance units (RU). One RU corresponds to approximatively $1 \mathrm{pg} / \mathrm{mm}^{2}$ of any biomolecule, as the specific response is based on the refractive index increment, which is similar for peptides, proteins, glycoproteins, lipids and nucleic acids. Interactions take place in a cell of approximatively $60 \mathrm{nl}$ volume. The continuous display of RU as a function of time gives a plot that is called a sensorgram, which provides a complete record of the progress of association and dissociation between the two molecules. After analyzing one interaction, the surface can be regenerated using an appropriate eluant solution that does not affect the activity of the immobilized ligand.

Purified human insulin (Peptide Institute, Osaka, Japan) was immobilized on a CM5 sensor chip surface using standard amine coupling in HBS (10 mM HEPES, $150 \mathrm{mM}$ $\mathrm{NaCl}, 3.4 \mathrm{mM}$ EDTA and $0.005 \%$ surfactant $\mathrm{P} 20$ at $\mathrm{pH} 7.4$ ) running buffer (flow rate: $5 \mu \mathrm{l} / \mathrm{min}$ ) at $25^{\circ} \mathrm{C}$. The carboxyl group at the CM5 sensor chip surface was activated with EDC/NHS (0.2 M N-ethyl-N-(3-diethylaminopropyl) carbodiimide and $0.05 \mathrm{M}$ N-hydroxysuccinimide) over a 7 minutes injection period and HBS buffer flow was maintained after the activation. Human insulin was dissolved in $10 \mathrm{mM}$ acetate buffer at $\mathrm{pH} 4.8$ and was injected during 16 minutes to achieve immobilization. The activated residue was then blocked with $1 \mathrm{M}$ ethanolamine hydrochloride $(\mathrm{pH} 8.5)$ injection. The immobilized surface was washed twice for 30 minutes by injections of $10 \mathrm{mM}$ glycine- $\mathrm{HCl}(\mathrm{pH} \mathrm{1.5)}$ after specimen exposure. The association rate constant $(\mathrm{ka})$ and the dissociation rate constant $(\mathrm{kd})$, and the KD were obtained by the analysis of the sensorgrams using BIA evaluation (ver. 3.1) software. The procedure was based on the following formula:

$$
\mathrm{dR} / \mathrm{dt}=\mathrm{k}_{\mathrm{a}} \mathrm{CR}_{\max }-\left(\mathrm{k}_{\mathrm{a}} \mathrm{C}+\mathrm{k}_{\mathrm{d}}\right) \mathrm{R}_{\mathrm{t}}
$$

where $R_{\max }$ is the maximum analyte binding capacity in RU and $R_{t}$ is the response in $R U$ at time $t$ and $C$ is the concentration of injected analyte.

The $\mathrm{ka}$ and $\mathrm{kd}$ were calculated from the $-(\mathrm{kaC}+\mathrm{kd})$ slope, which was given by the plot of $\mathrm{dR} / \mathrm{dt}=-\mathrm{kd}+\mathrm{Rt}$ plot. The KDs were determined by kd/ka.

\section{Deinsulinization of the insulin antibody complex in patient's serum}

Deinsulinization was carried out according to the methods of Eguchi et al (12) and Dixon et al (13). To separate and remove insulin from the insulin antibody complex in the serum, $125 \mu \mathrm{l}$ of $0.12 \mathrm{~N} \mathrm{HCl}$ and $50 \mu \mathrm{l}$ of dextran-coated charcoal were added to $100 \mu \mathrm{l}$ of serum at $4^{\circ} \mathrm{C}$. After shaking for 5 minutes, an additional $125 \mu \mathrm{l}$ of $0.12 \mathrm{~N} \mathrm{HCl}$ and $600 \mu \mathrm{l}$ of HBS were added and then centrifuged at 3,000 rpm for 30 minutes at $4^{\circ} \mathrm{C}$. The supernatant was filtrated with a
0.22 filter (Millipore Co., Ltd) and the filtrate was frozen at $-80^{\circ} \mathrm{C}$ until required for laboratory analysis.

For affinity analysis of insulin antibodies, CM-dextran sodium salt (Fluka Chemie AG, Switzerland) was added to each sample in order to eliminate the nonspecific reaction. CM-dextran was dissolved in HBS buffer and the final concentration was $10 \mu \mathrm{g} / \mathrm{ml}$. We confirmed that over $97.8 \%$ of the insulin was removed from the serum by this method (data not shown).

\section{Quantitation of insulin antibody in the serum}

A standard curve (RU vs. antibody concentration) was prepared by using an anti-human insulin monoclonal antibody (Japan Biotest Laboratory, Tokyo, Japan). The concentrations of anti-human insulin monoclonal antibody used were $1.00 \times 10^{-2}, 5.00 \times 10^{-3}, 2.50 \times 10^{-3}, 1.25 \times 10^{-3}$, and $6.25 \times$ $10^{-4} \mathrm{mg} / \mathrm{ml}$, respectively.

To measure the concentration of insulin antibodies in sera, we prepared CM5 sensor chips that immobilized human insulin and the patient's serum, which was deinsulinized as mentioned above. The patient's serum was injected over 180 seconds and the binding level was measured after $150 \mathrm{sec}-$ onds in HBS running buffer (flow rate: $10 \mu \mathrm{l} / \mathrm{min}$ ). The immobilized surface was washed twice for 30 minutes by injections of $10 \mathrm{mM}$ glycine- $\mathrm{HCl}(\mathrm{pH} 1.5)$. Using the difference between the binding levels of the serum and the control, the concentration of the patient's insulin antibodies was assessed using a standard curve.

\section{Removal of IgG}

IgG sorb (Enzyme Center, Malden, MA, U.S.A.) was used to remove $\operatorname{IgG}$ from the serum. Deinsulinized serum was incubated for 10 minutes with $\operatorname{IgG}$ sorb, and centrifuged at $10,000 \mathrm{rpm}$ for 1 minute at $4^{\circ} \mathrm{C}$ to remove material that bound non-specifically to the adsorbent. CM-dextran $(40 \mu \mathrm{l})$ was added to the collected supernatant and then assayed by BIAcore $^{\mathrm{TM}}$. The control consisted of serum diluted with the same amount of HBS buffer and $40 \mu \mathrm{l}$ of CM-dextran.

\section{Scatchard analysis}

The patient's serum that had been deinsulinized was used for the Scatchard analysis (8), which was performed as per the method previously reported by Eguchi et al (12). Briefly, the serum was incubated with $100 \mu \mathrm{l}$ of ${ }^{125} \mathrm{I}$-human insulin in the presence of $100 \mu \mathrm{l}$ of serial concentrations of human insulin solution and after precipitation with PEG 6,000, the radioactivity of the pellets was counted with an automatic gamma counter. We performed Scatchard analysis in 5 of 8 patients exhibiting the insulin antibodies.

\section{Statistical analysis}

Data are presented as the mean \pm standard deviation ( $\mathrm{M} \pm$ SD). Differences between groups were evaluated by the Mann-Whitney U-test for comparison of the hypoglycemic episode-positive and -negative groups. $\mathrm{P}$ values less than 0.05 were regarded as significant. 


\section{Results}

\section{Immobilization}

To measure the concentration of insulin antibodies, purified human insulin was immobilized on a CM5 sensor chip by the amine coupling procedure. The immobilized quantity was $1,760 \mathrm{RU}$. In order to measure the affinity of insulin antibodies, it was necessary to prepare a sensor chip with less immobilized quantity. The immobilized quantity for this measurement was $360 \mathrm{RU}$.

\section{Identification of specific binding for insulin on the sen- sor chip}

Figure 1 shows a representative example (patient No. 5) that was analyzed by BIAcore ${ }^{\mathrm{TM}}$. Figure $1 \mathrm{~A}$ shows the pattern of a deinsulinized sample analyzed with a sensor chip to measure the concentration of insulin antibodies. The difference between the sample (continuous line) and the control (HBS buffer, broken line) reveals that insulin antibodies bound insulin on the sensor chip (specific binding).

To verify the insulin antibodies shown in Fig. 1A, we analyzed the patient sample after adding an excess amount of insulin under the same conditions. As shown in Fig. 1B, specific binding almost disappeared after the addition of the excess amount of insulin.

\section{Removal of IgG}

A representative example is shown in Fig. 1C. The continuous line represents the results of the sample assay after IgG sorb and the broken line represents the corresponding control by BIAcore ${ }^{\mathrm{TM}}$. After removal of IgG by the treatment with IgG sorb, the specific binding of insulin was almost diminished. IgG sorb was examined in another sample (patient No. 4), and the results were found to be similar to the first case.

\section{Standard curve of insulin antibody}

Figure 2 shows the standard curve for insulin antibody using anti-human insulin monoclonal antibody as a standard. The standard curve was constructed by using the BIAcore ${ }^{\mathrm{TM}}$ software. It was thought that the standard curve was representative of a good correlation.

\section{Concentration of insulin antibodies in the sera}

Table 2 shows the concentration of insulin antibodies in the sera as measured by BIAcore ${ }^{\mathrm{TM}}$. In 8 patients, the concentration ranged from 2.91 to $16.3 \mu \mathrm{g} / \mathrm{ml}$. On the other hand, insulin antibodies were not detected in any of the sera of the corresponding controls.

\section{Affinity of patient's insulin antibodies}

To measure the affinity of the patient's antibodies and mouse monoclonal antibody, a sensor chip with a less immobilized quantity was prepared as described previously. As shown in Table 2, a 1:1 (Langmuir) binding was used for the fitting model. In patients with hypoglycemic episodes, the apparent affinity of the insulin antibody ranged from 5.53 to $2.49 \times 10^{4} \mathrm{Ms}^{-1}$ for the ka, from $2.62 \times 10^{-4}$ to $1.15 \times 10^{-3} \mathrm{~s}^{-1}$ for the $\mathrm{kd}$ and from $1.05 \times 10^{-8}$ to $2.09 \times 10^{-4} \mathrm{M}$ for the KD. In the patients without hypoglycemic episodes, the apparent affinity of the insulin antibody ranged from $1.35 \times 10^{3}$ to $1.52 \times$ $10^{6} \mathrm{Ms}^{-1}$ for the ka, from $1.91 \times 10^{-4}$ to $2.47 \times 10^{-3} \mathrm{~s}^{-1}$ for the $\mathrm{kd}$ and from $1.62 \times 10^{-9}$ to $1.41 \times 10^{-7} \mathrm{M}$ for the KD. The KD values were significantly higher in the hypoglycemic episodepositive group $\left(5.44 \pm 10.3 \times 10^{-5} \mathrm{M} ; \mathrm{p}<0.05\right)$ than in the hypoglycemic episode-negative group $\left(3.73 \pm 6.91 \times 10^{-8} \mathrm{M}\right)$. No significant differences in the concentration, the ka and the kd values were noted between the groups. The concentration, $\mathrm{ka}, \mathrm{kd}$, and $\mathrm{KD}$ of insulin antibodies measured by BIAcore $^{\mathrm{TM}}$ did not correlate with TIRI, FIRI or ${ }^{125}$ I-labeled human insulin binding.

The affinity of anti-human insulin antibodies (mouse monoclonal) as measured by the BIAcore ${ }^{\mathrm{TM}}$ system was $4.31 \times 10^{5} \mathrm{Ms}^{-1}(\mathrm{ka}), 5.21 \times 10^{-8} \mathrm{~s}^{-1}(\mathrm{kd})$ and $1.21 \times 10^{-13} \mathrm{M}(\mathrm{KD})$.

\section{Scatchard analysis}

As shown in Table 2, although the k1 values tended to be higher in the hypoglycemic episode-positive than in the hypoglycemic episode-negative group, there were no differences between the groups for the b1, k2 and b2 values.

\section{Discussion}

In this study, we describe a new method for quantitative and qualitative analysis of insulin antibodies in the sera of diabetic patients using the BIAcore ${ }^{\mathrm{TM}}$ system.

To calculate the apparent affinity of the insulin antibody, the concentration of insulin antibodies is a very important factor for the BIAcore ${ }^{\mathrm{TM}}$ system software. In this study, we first tried to measure the concentration of the insulin antibody in diabetic patients. We decided to use mouse monoclonal anti-human insulin antibody as the control for this experiment because there is no standard human anti-insulin antibody available. Since the antibodies to the exogenous insulin are generally considered to be polyclonal and consist of various components with different affinities, the mouse monoclonal antibody we selected in this study might show different time constants for the antigen-antibody interaction compared with those of patients. Our results indicated that the $\mathrm{kd}$ and the KD values for the patients that possessed the insulin antibody in their sera were more than ten thousand times larger than that for mouse anti-insulin monoclonal antibody. Additionally the KD of the hypoglycemic episodepositive group was significantly higher than that for the hypoglycemic episode-negative group. These results suggest that the patients with recurrent hypoglycemic episodes may have insulin antibodies that dissociate more easily from the immune-complex in the sera. In other words, the existence and the characteristics of the insulin antibodies have important causative roles in hypoglycemic episodes.

Berson et al $(5,6)$ demonstrated that almost all insulintreated patients possess insulin-binding immunoglobulins. 

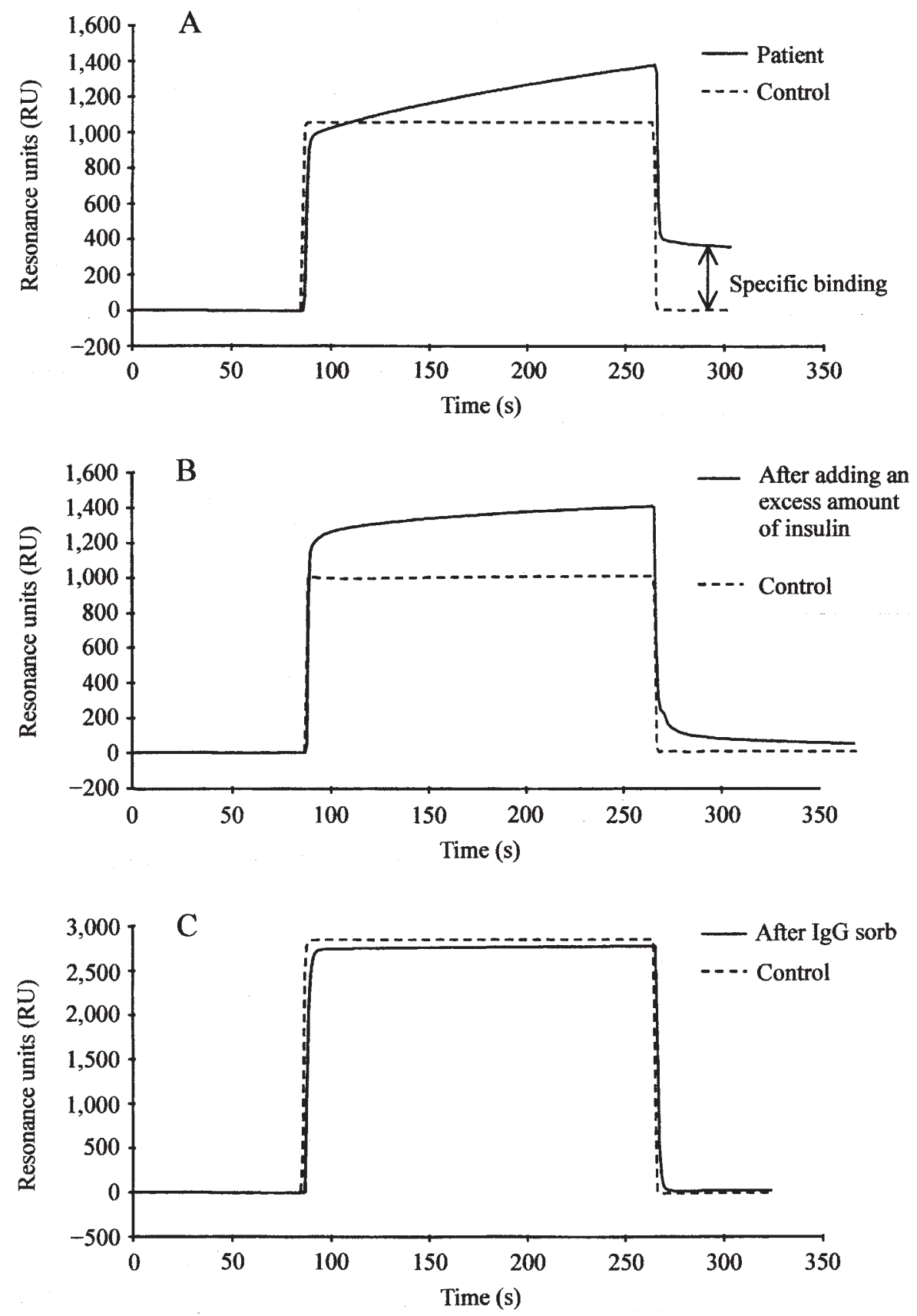

Figure 1. Example of BIAcore ${ }^{\mathrm{TM}}$ analysis (patient No. 5). A: The pattern for a deinsulinization sample. The difference between the sample (continuous line) and the control (broken line) reveals that insulin antibodies bound insulin on the sensor chip (specific binding). B: The results of the sample assay after adding an excess amount of insulin. The specific binding almost disappeared. C: The results of the sample assay after IgG sorb. After removal of IgG the specific binding was abated.

These antibodies were later shown to be polyclonal $\operatorname{IgG}(14)$. In our study, the insulin antibody that presented in the patients with exogenous insulin treatment may also belong to the IgG immunoglobulin class because we found that the specific binding was almost completely diminished in the serum of patients after the removal of $\operatorname{IgG}$ by $\operatorname{IgG}$ sorb. However, in this study we only examined two samples. Even so, it did seem that these reactions were associated with $\operatorname{IgG}$ class immunoglobulins.

Since patients with insulin autoimmune syndrome (IAS) 


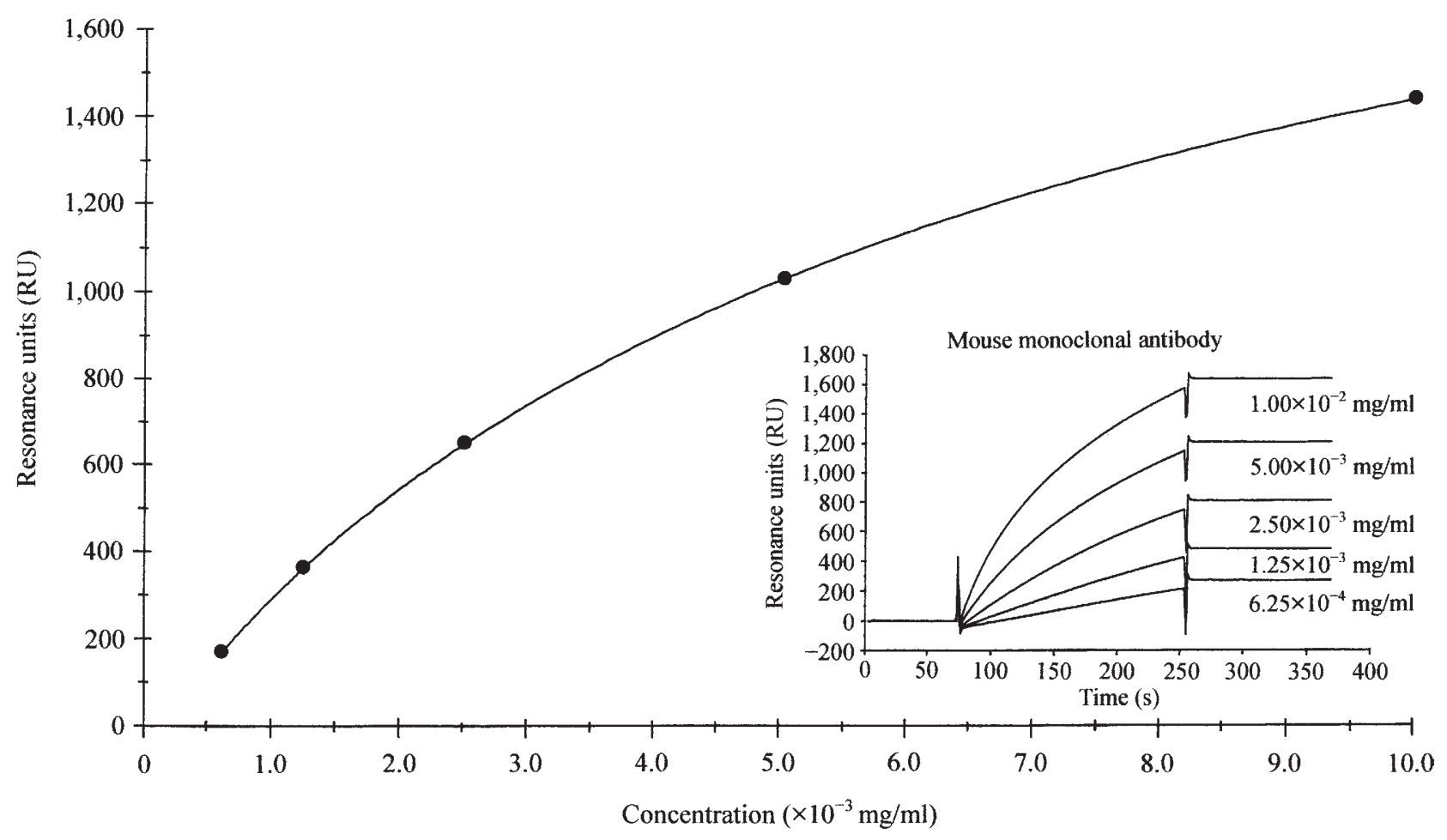

Figure 2. A standard curve (RU vs. antibody concentration) was prepared by using an anti-human insulin monoclonal antibody. The concentrations of anti-human insulin monoclonal antibody used were $1.00 \times 10^{-2}, 5.00 \times 10^{-3}, 2.50 \times 10^{-3}, 1.25 \times$ $10^{-3}$ and $6.25 \times 10^{-4} \mathrm{mg} / \mathrm{ml}$, respectively.

also have insulin antibodies and show frequent hypoglycemic episodes, it is necessary to be able to distinguish between the two types of patients. IAS can be characterized by spontaneous hypoglycemia that occurs without any evidence of exogenous insulin administration. Additionally, HLADR4 and DRB*0406 genotypes are common in patients with IAS $(1,15)$. However, there was no history of spontaneous hypoglycemia before insulin administration in any of our patients and none of the subjects was treated with insulin until after the diagnosis of diabetes mellitus. And since our patients had different HLA typing from that which is seen in IAS (Table 1), they can be distinguished from those patients with IAS.

To date few papers describe the insulin antibodies analyzed by Scatchard analysis $(1,12,16)$. One of these reports using IAS patients showed that the insulin antibodies of insulin-treated diabetic patients with hypoglycemia exhibit a much smaller high-affinity $\mathrm{k} 1$ value and a much larger lowcapacity b1 value than the $\mathrm{k} 1$ and $\mathrm{b} 1$ values seen for insulin antibodies in patients without hypoglycemia (12). In the Scatchard analysis that was performed in 5 of our patients, the results that were found indicated that the $\mathrm{k} 1$ values tended to be even higher in the hypoglycemic episodepositive group than in the hypoglycemic episode-negative group. Additionally, there was no difference found for the b1 values between the groups (Table 2). On the contrary, in the hypoglycemic episode-positive group, the KD values were significantly larger and the ka values tended to be smaller than those in the hypoglycemic episode-negative group. These results also corresponded with the clinical features observed.

With regard to those points, the apparent affinity, as measured by the BIAcore ${ }^{\mathrm{TM}}$ system, seems to more closely reflect the situation of the serum than the data obtained from a Scatchard analysis since the BIAcore ${ }^{\mathrm{TM}}$ system can easily measure low-affinity interactions that are less than $10^{-4} \mathrm{M}$ $\mathrm{kd}$. The affinity of exogenous insulin antibodies is one of the causes of hypoglycemia. Since hypoglycemia has been considered to result from low-affinity insulin antibodies, the BIAcore $^{\mathrm{TM}}$ system can measure the kd regardless of the state of the affinity in the sera. Based on these results, the BIAcore $^{\mathrm{TM}}$ system can more extensively evaluate insulin antibodies than the Scatchard analysis.

The mechanism of the immunogenicity of exogenous human insulin antibody is still unknown. Several factors are considered to influence the production of insulin antibodies, such as genetic factors, mode of insulin administration, and degree of purity and species of insulin. In the future, we will be able to identify the epitopes and the mechanism of insulin antibody production by using the BIAcore ${ }^{\mathrm{TM}}$ system.

In diabetic patients treated with human recombinant insulin, we need to pay more attention to the presence of anti- 
KURE et al

Table 2. Comparison of Concentration, Affinity and Scatchard Analysis of Insulin Antibodies between Hypoglycemic Episodepositive and -negative Group

\begin{tabular}{|c|c|c|c|c|c|c|c|c|c|}
\hline \multirow[b]{2}{*}{$\begin{array}{c}\text { Patient } \\
\text { no. }\end{array}$} & \multirow[b]{2}{*}{$\begin{array}{l}\text { Hypoglycemic } \\
\text { episode }\end{array}$} & \multicolumn{4}{|c|}{ BIAcore $^{\mathrm{TM}}$} & \multicolumn{4}{|c|}{ Scatchard analysis } \\
\hline & & $\begin{array}{l}\text { Concentration } \\
(\mu \mathrm{g} / \mathrm{ml})\end{array}$ & $\begin{array}{c}\mathrm{ka} \\
\left(\mathrm{Ms}^{-1}\right)\end{array}$ & $\begin{array}{l}\mathrm{kd} \\
\left(\mathrm{s}^{-1}\right)\end{array}$ & $\begin{array}{l}\mathrm{KD} \\
(\mathrm{M})\end{array}$ & $\begin{array}{c}\mathrm{k} 1 \\
(l / \mathrm{mol})\end{array}$ & $\begin{array}{c}\text { b1 } \\
(l / \mathrm{mol})\end{array}$ & $\begin{array}{c}\mathrm{k} 2 \\
(l / \mathrm{mol})\end{array}$ & $\begin{array}{c}\text { b2 } \\
(l / \mathrm{mol})\end{array}$ \\
\hline 1 & + & 4.81 & 5.53 & $1.15 \times 10^{-3}$ & $2.09 \times 10^{-4}$ & N.D. & N.D. & N.D. & N.D. \\
\hline 2 & + & 4.10 & $4.59 \times 10^{3}$ & $8.02 \times 10^{-4}$ & $1.75 \times 10^{-7}$ & $2.17 \times 10^{9}$ & $1.91 \times 10^{-10}$ & $2.53 \times 10^{5}$ & $1.16 \times 10^{-7}$ \\
\hline 3 & + & 2.91 & 64.1 & $5.32 \times 10^{-4}$ & $8.30 \times 10^{-6}$ & $2.66 \times 10^{9}$ & $1.46 \times 10^{-9}$ & $2.94 \times 10^{6}$ & $1.33 \times 10^{-8}$ \\
\hline 4 & + & 10.8 & $2.49 \times 10^{4}$ & $2.62 \times 10^{-4}$ & $1.05 \times 10^{-8}$ & N.D. & N.D. & N.D. & N.D. \\
\hline $\mathrm{M} \pm \mathrm{SD}$ & & $5.65 \pm 3.51$ & $7.39 \pm 11.9 \times 10^{4}$ & $6.87 \pm 3.80 \times 10^{-4}$ & $5.44 \pm 10.3 \times 10^{-5 *}$ & - & - & - & - \\
\hline 5 & - & 16.3 & $4.20 \times 10^{5}$ & $8.35 \times 10^{-4}$ & $1.99 \times 10^{-9}$ & $1.65 \times 10^{7}$ & $2.68 \times 10^{-9}$ & $9.88 \times 10^{4}$ & $2.40 \times 10^{-7}$ \\
\hline 6 & - & 4.15 & $1.83 \times 10^{5}$ & $8.37 \times 10^{-4}$ & $4.59 \times 10^{-9}$ & $2.44 \times 10^{6}$ & $1.16 \times 10^{-8}$ & $8.32 \times 10^{4}$ & $1.73 \times 10^{-7}$ \\
\hline 7 & - & 3.38 & $1.35 \times 10^{3}$ & $1.91 \times 10^{-4}$ & $1.41 \times 10^{-7}$ & $3.66 \times 10^{7}$ & $7.85 \times 10^{-10}$ & $2.87 \times 10^{5}$ & $3.67 \times 10^{-8}$ \\
\hline 8 & - & 7.71 & $1.52 \times 10^{6}$ & $2.47 \times 10^{-3}$ & $1.62 \times 10^{-9}$ & N.D. & N.D. & N.D. & N.D. \\
\hline $\mathrm{M} \pm \mathrm{SD}$ & & $7.90 \pm 5.94$ & $5.31 \pm 6.81 \times 10^{5}$ & $10.8 \pm 9.73 \times 10^{-4}$ & $3.73 \pm 6.91 \times 10^{-8}$ & - & - & - & - \\
\hline \multicolumn{2}{|c|}{ Mouse monoclonal antibody } & & $4.31 \times 10^{5}$ & $5.21 \times 10^{-8}$ & $1.21 \times 10^{-13}$ & N.D. & N.D. & N.D. & N.D. \\
\hline
\end{tabular}

Data are presented as mean $(\mathrm{M}) \pm \mathrm{SD} .{ }^{*} \mathrm{p}<0.05$ compared with hypoglycemic episode-negative group. N.D.: not determined.

insulin polyclonal antibodies. We strongly recommend that the measurement of serum insulin antibodies should be done in patients who develop insulin resistance and hypoglycemia.

\section{References}

1) Uchigata $Y$, Tokunaga K, Nepom G, et al. Differential immunogenetic determinants of polyclonal insulin autoimmune syndrome (Hirata's disease) and monoclonal insulin autoimmune syndrome. Diabetes 44: 1227-1232, 1995.

2) Schernthaner G. Immunogenicity and allergenic potential of animal and human insulins. Diabetes Care 16 (Suppl 3): 155-165, 1993.

3) Van Haeften TW. Clinical significance of insulin antibodies in insulintreated diabetic patients. Diabetes Care 12: 641-648, 1989.

4) Fineberg SE, Galloway JA, Fineberg NS, Rathbun MJ, Hufferd S Immunogenicity of recombinant DNA human insulin. Diabetologia 25: 465-469, 1983

5) Berson SA, Yalow RS, Bauman A, Rothschild MA, Newerly K. Insulin $I^{131}$ metabolism in human subjects: Demonstration of insulin binding globulin in the circulation of insulin-treated subjects. J Clin Invest 35: 170-190, 1956.

6) Berson SA, Yalow RS. Quantitative aspects of the reaction between insulin and insulin-binding antibody. J Clin Invest 38: 1996-2016, 1959.

7) Van Haeften TW, Krom BA, Gerich JE. Prolonged fasting hypoglycemia due to insulin antibodies in patient with non-insulin-dependent dia- betes mellitus: effect of insulin withdrawal on insulin-antibody-binding kinetics. Diabetes Care 10: 160-163, 1987.

8) Scatchard G. The attraction of proteins for small molecules and ions. Ann NY Acad Sci 51: 660-672, 1949.

9) Jonsson U, Fagerstam L, Ivarsson B, et al. Real-time biospecific interaction analysis using surface plasmon resonance and a sensor chip technology. Biotechniques 11: 620-627, 1991.

10) Karlsson R, Michaelsson A, Mattsson L. Kinetic analysis of monoclonal antibody-antigen interactions with a new biosensor based analytical system. J Immunol Methods 145: 229-240, 1991.

11) Uchigata Y, Omori Y, Nieda M, Kuwata S, Tokunaga K, Juji T. HLADR4 genotype and insulin-processing in insulin autoimmune syndrome. Lancet 340: 1467, 1992.

12) Eguchi $Y$, Uchigata $Y$, Yao K, Yokoyama H, Hirata Y, Omori $Y$. Longitudinal changes of serum insulin concentration and insulin antibody features in persistent insulin autoimmune syndrome (Hirata's disease). Autoimmunity 19: 279-284, 1994.

13) Dixon K, Exon PD, Malins JM. Insulin antibodies and the control of diabetes. Q J Med 176: 543-553, 1975.

14) Kumar D. Insulin antibodies: an analysis of immunoglobulin G subclasses. Diabetes 35: 189A, 1986

15) Uchigata $Y$, Kuwata S, Tokunaga K, et al. Strong association of insulin autoimmune syndrome with HLA-DR4. Lancet 339: 393-394, 1992.

16) Goldman J, Baldwin D, Pugh W, Rubenstein AH. Equilibrium binding assay and kinetic characterization of insulin antibodies. Diabetes 27: 653-660, 1978. 